\title{
Technical Efficiency of Yam Commodity in Semarang Regency
}

\author{
Avi Budi Setiawan ${ }^{1}$, Ngatindriatun', Karsinah ${ }^{3}$ \\ 1,3 Faculty of Economics, Universitas Negeri Semarang, Indonesia \\ 2 Bina Nusantara University, Indonesia
}

\section{Article Info}

Article history:

Received: 1 July 2019;

Accepted: 22 September 2019;

Published: 1 October 2019.

Keywords:

Efficiency; Yam; Semarang regency.

\begin{abstract}
Semarang Regency has the largest area of yam harvest in Central Java. Although the area of yam harvest in Semarang Regency is much more than other districts including Karanganyar Regency, the production and productivity level of yam in Semarang Regency are lower compared to Karanganyar Regency. The tendency of increasing yam harvest area in Semarang Regency was not followed by an increase in production. This study aims to analyze the efficiency of yam farming in Semarang Regency. The sample is 97 farmers with the data analysis technique is stochastic frontier regression. Based on the results, an average efficiency is 0.75 . It implies that yam farmers have not been able to combine the use of land area, seeds, urea, SP-36 and phonska. The results of price efficiency is 19.233. The results of these calculations indicate that the use of production factors in yam has not efficiency. Farmers can optimize the use of production factors by adding production factors. The level of economic efficiency is 14.433 , it indicate that the use of production factors has not been efficient based on economic aspects, because the calculation results is more than 1.
\end{abstract}

\begin{abstract}
Abstrak
Kabupaten Semarang adalah kabupaten yang memiliki luas panen ubi jalar terluas di Jawa Tengah. Walaupun luas panen ubi jalar di Kabupaten Semarang lebih luas dibandingkan dengan kabupaten lainnya termasuk Kabupaten Karanganyar, namun produksi dan produktivitas ubi jalar di Kabupaten Semarang selalu dibawah Kabupaten Karanganyar. Kecenderungan peningkatan luas panen tidak diikuti oleh peningkatan produksi. Penelitian ini bertujuan untuk melihat tingkat efisiensi usahatani ubi jalar. Dalam penelitian ini digunakan sampel sebanyak 97 petani dengan teknik analisis regresi frontier stokastik. Berdasarkan hasil penelitian, diperoleh nilai efisinsi sebesar 0.751. Para petani ubi jalar di Kabupaten Semarang belum mampu mengkombinasikan penggunaan faktor produksi luas lahan, benih, pupuk kandang, pupuk urea, pupuk SP36 dan pupuk phonska untuk menghasilkan produksi ubi jalar yang optimal. Hasil penghitungan efsisensi harga sebesar 19.233. Hasil tersebut menunjukkan bahwa penggunaan faktor produksi belum tercapai efisiensi. Petani ubi jalar dapat mengoptimalkan penggunaan faktor produksi dengan cara menambah faktor produksi usahatani ubi jalar agar efisiensi. Hasil penghitungan efisiensi ekonomi sebesar 14.433 menunjukkan bahwa penggunaan faktor produksi belum efisien berdasarkan aspek ekonomi, karena hasil penghitungan menunjukkan angka lebih dari 1.
\end{abstract}

\section{How to Cite:}

Setiawan, A. B., Ngatindriatun, N., \& Karsinah, K. (2019). Technical Efficiency of Yam Commodity in Semarang Regency. Jurnal Pendidikan Ekonomi \& Bisnis, 7(2), 137-145. https://doi.org/10.21009/JPEB.007.2.5 


\section{INTRODUCTION}

Agricultural sector is one of the important sectors in national development, especially those related to food security and sustainability. The management and utilization of agricultural products are expected to carried out in a more planned programs with optimum utilization Setiawan (2015). This sectors also provide the raw materias for another sector such as industrial and trade sectors.

In addition to its large contribution to the National GDP, the agricultural sector is also the sector that absorbs the largest workforce in Indonesia. During the 2015-2018 period, the agricultural sector become the sector with the largest share of employment for about 29.68 percent of the total employment. However, iIn 2018, employment decreased to the level 28.79 percent (BPS, 2018). Agricultural labor (in the narrow sense) is the largest labor force with a total of 36.91 million people in February 2018. This number constitutes 28.23 percent of the total Indonesian workforce. While the number of workers in February 2017 amounted to 36.96 million people decreased in February 2018 which amounted to 29.2 percent (PUSDATIN, 2018). Therefore, the role of the agricultural sector in the Indonesian economy is important. According to the BPS (2018), the agricultural sector in Indonesia is divided into five sub-sectors namely the food crop, plantation, forestry, livestock and fisheries.

The food sources of Indonesians is rice. Its more than 90 percent of peoples rely on rise as a carbohydrates source.. Indonesias rice consumption in $2002107.71 \mathrm{~kg} /$ capita/year decreased to $96.33 \mathrm{~kg} /$ capita/year in 2018 (PUSDATIN, 2019). Thus, the dependence of the Indonesian population on rice, so there is little disruption in rice production such as crop failure, supply becomes disrupted, and selling prices increase (Andoko, 2002). Food diversification can be an alternative to the problem. Policies that are carried out in food diversification can be done through developing diverse carbohydrate food consumption, developing and increasing the attractiveness of non-rice carbohydrate food etc. Lastly, it needs roduct development and quality of non-rice carbohydrate food products which are highly nutritious and allow for developed (Nurmalina, 2008).

Yam is one of the main food sources of highly nutritious non-rice carbohydrates and has the potential to be developed as a support in the development of a food diversification program (Zuraida, 2009). This commodity is easily cultivated, the price per kilogram is quite cheap, it can be processed in various types of food and specialties in terms of nutritional value, namely as a source of calories, vitamins $\mathrm{A}$ and $\mathrm{C}$ and minerals. Yam demand is mostly (85 percent) meet human consumption needs, around 2 percent for animal feed, 2.5 percent for industrial raw materials and 10.5 percent is lost due to harvest and post-harvest processes (Defri, 2011). Yam (Ipomoea batatas L) is one of the important tubers throughout the world with a production of more than 133 million tons, consumed by millions of humans, and is included in seven important plant sources of carbohydrates after wheat, rice, corn, potatoes, barley and cassava (Waramboi, et al., 2011). This plant is able to adapt in areas that are less fertile and dry (Zhang \& Oates, 1999). Yam productivity is quite high compared to rice and cassava and sweet potato production period until the harvest is only four months (Puslitbangtan, 2007).

One type of yam that is commonly found in Indonesia is purple yam. Where the purple color of yam due to the presence of anthocyanin purple pigments (Santoso and Estiasih, 2014). Anthocyanin contained in yam functions as an antioxidant, anticancer, amtibateria, has a protective power against damage to the liver, heart and stroke (Ekoningtyas et al., 2016). Yam or purple yam has the Latin name Ipomoea batatas $\mathrm{L}$, where this plant is a creeping plant that belongs to the Convoloulaceae family which is still a family with kale and of course this plant is a plant that can thrive in the tropics (Suparman, 2007). Yam production has been cultivated in various provinces in Indonesia, especially in Central Java Province. It is including in the four largest yam producing provinces in Indonesia after West Java, East Java, and Papua. Central Java Province had a yam harvest area of 5.870 hectares, yam production of 158,942 tons, and productivity of $270.77 \mathrm{kw} / \mathrm{ha}$ (Kementan, 2019). 


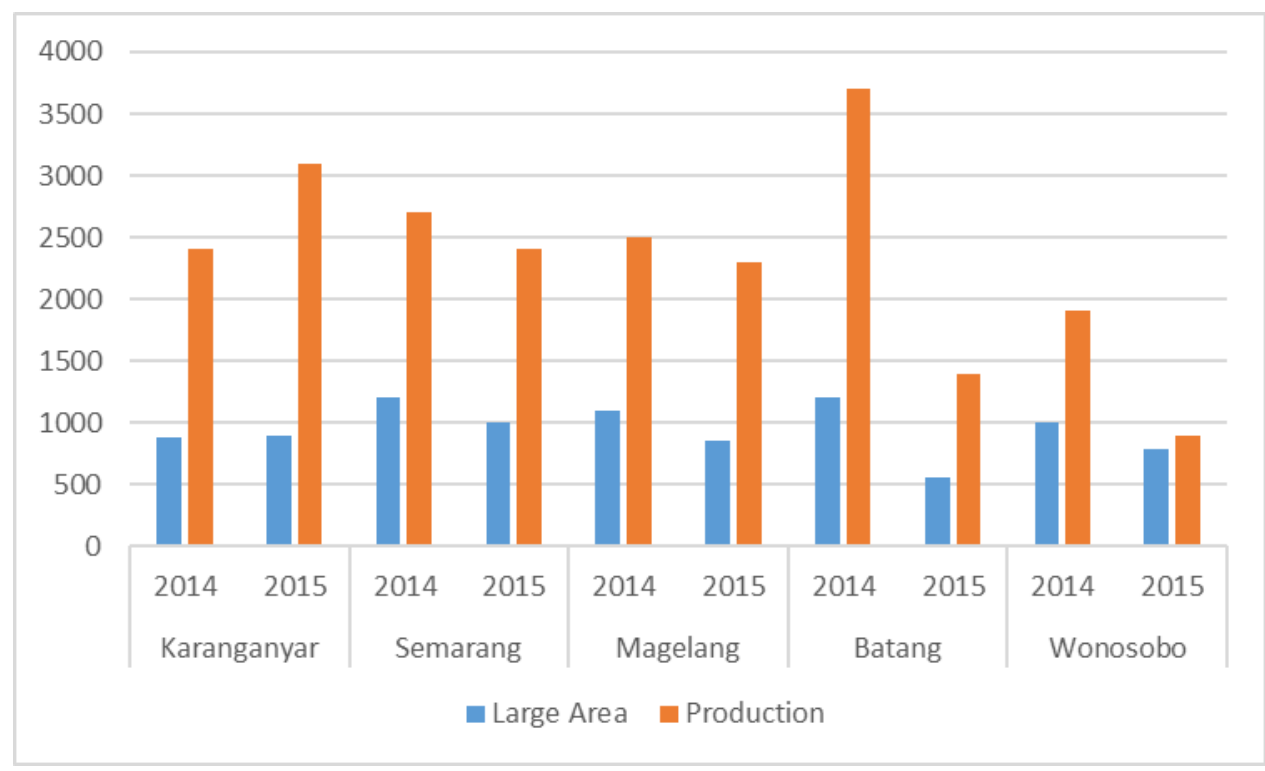

Source: BPS (2016), data processed

Figure 1. Harvest Area, Production, and Productivity of Yam in Central Java in 2014-2015.

Figure 1 shows that in 2014 to 2015 yam production in five districts in Central Java experienced fluctuations. When viewed in terms of production, the largest producing district in Central Java is Karanganyar Regency and then followed by Semarang Regency, Magelang Regency, Batang Regency and Wonosobo Regency. Meanwhile, from the side of the harvested area, the Semarang Regency is a district that has the widest harvested area in Central Java. Semarang Regency in 2014 had an area of 1,186 hectares and decreased in 2015 to 981 hectares. The decrease in harvested area is caused by land conversion on fertile lands. Although the area of harvest in Semarang Regency is wider than other districts including Karanganyar Regency, the production and productivity of yam in Semarang Regency are lower than Karanganyar Regency.

Table 1. Yam Production in the Center of Yam in Semarang Regency In 2017 (tons)

\begin{tabular}{ll}
\hline Subdistrict & $\mathbf{2 0 1 7}$ \\
\hline Sumowono & 3783 \\
Bergas & 5030 \\
Bandungan & 4150 \\
\hline
\end{tabular}

Source: BPS Semarang regency (2018), data processed

Based on table 1, it can be seen that among the 3 sub-districts that became centers of production in Semarang Regency, the District that had the highest yam production during the 2017 period was Bergas District. However, the production in Bergas District during that period tended to decrease. This was due to erratic weather and land use change due to high demand for other commodities such as mustard, cabbage, and others. In the other hand, all of distric has a similar characteristic. Its located in a highland, the similar soil characteristic.

The efforts to meet the demand for yam in Semarang Regency needed an increase in production to maintain the availability of supply. One way is to encourage increased production in yam cultivation in Semarang Regency. An increase in sweet potato production is expected to increase the productivity of yam in the area which is the center of production in Semarang Regency. Karama (2003) states that the low productivity of cassava and yam is partly due to: (a). Most farmers still use local varieties whose productivity is generally low, (b). The quality of the 
seeds used is often poor, (c). Cassava and yam are mostly cultivated on dry land which is often of lower fertility compared to paddy fields, (d). Plant management is done simply with a modest input.

Semarang Regency is one of the five largest yam producing districts in Central Java. When viewed in terms of production, the Semarang Regency ranks second largest producer of yam after Karanganyar Regency. However, when viewed from the side of harvested area, Semarang Regency is a district that has the widest yam harvest area in Central Java. Although the area of yam harvest in Semarang Regency is wider than other districts including Karanganyar Regency, the production and productivity of yam in Semarang Regency are always below Karanganyar Regency.

In 2015, the area of yam harvest in Karanganyar Regency was 868 hectares with a production of 31,076 tons and a productivity of $358.01 \mathrm{kw} /$ ha. While Semarang Regency in the same year with a harvest area of 981 hectares was only able to produce a production of 24,812 tons and a productivity of $252.92 \mathrm{kw} / \mathrm{ha}$. Yam harvested area in Semarang Regency in 2011-2015 experienced fluctuations and tended to increase although it had decreased in 2015. However, the tendency of increasing yam harvested area in Semarang Regency was not followed by an increase in production.

Yam production in Semarang Regency in 2011-2015 actually tends to decrease. While the productivity of yam in Semarang Regency in that year also tended to decrease even though in 2015 it had increased $\mathrm{kw} /$ ha from the previous year by 232.39 to 252.82 . The decline in production and productivity in Semarang Regency is caused by the lack of knowledge of farmers in the efficient use of inputs. According to Mubyarto (1994: 78), efforts to increase agricultural production as a realization of agricultural development are carried out by way of extensification, intensification, and diversification. Extensification business generally means expanding agricultural land by holding new land clearing. Effort intensification is the use of more factors of labor and capital production over a certain parcel of land to achieve greater production. Agricultural diversification is diversifying agricultural products by utilizing land, water and new technologies.

The explanation above shows that in yam production, the using of production factors is quite important to increase the output. There are several important production factors such as land area, fertilizer, seed, labor and perticide. Therefore, the combination of input is neccessary to maximizing the harvest.

In the other research, Setiawan (2015) states that the using of food crop commodities tend to diminishing return due to the land quality. However, Prihandayani (2013) also states that the using of fertilizer, seed also contributes towards the productivity. This research try to fill the gap research between both of previous research. The yam productivity tend to decrease due to the inneficient of production factors. Therefore, this research use more variables of fertilizer such as organic fertilizer, urea, TSP and phonska fertilizer. Comparing to previous research that only uses one fertilizer variables. The using of each fertilizers is quite important due to the differences of function.

\section{METHOD}

Researchers conducted research in three villages, namely Bergas Kidul Village, Gebugan Village and Gondoriyo Village. The three villages are the villages with the highest number of yam among sweet potato producing villages in the District of Bergas, therefore it is expected to be able to describe the general and overall situation of farming in the District of Semarang's Bergas. The total farmers of the three villages is 3400 . The sampling method in this study uses purposive sampling. The sample in this study was farmers in Semarang Regency. Based on the population to be studied and with a fault tolerance of $10 \%$, the following samples can be determined Arikunto (1992):

$\mathrm{n}=\frac{3.400}{1+3.400(0,01)}=97$

From calculations using the Slovin formula above, the samples obtained were 97 farmers. 
The number of samples taken in this study were 97 yam farmers in Bergas Kidul Village, Gebugan Village and Gondoriyo Village. Taking respondents is determined randomly with the Proportional Random Sampling method. The allocation of proportional sample members is as follows: therefore, the number of samples taken was 40 respondents in the village of Bergas Kidul, 37 in the village of Gebugan and 20 in the village of Gondoriyo with the characteristics of landowners and land tenants. Simple random sampling was taken, so that the total number of samples was 97 respondents or 97 yam farmers from 3 sample villages in the District of Bergas, Semarang Regency.

This research was conducted using a descriptive study approach by collecting data consisting of primary data and secondary data. Primary data obtained from field surveys concerning objects to be examined and adjusted to the needs. Data was also obtained from interviews with local community respondents. The secondary data is data obtained from notes or other sources that have been there before and processed then presented in the form of texts, written works, research reports, books and so forth. The secondary data needed is obtained from the Semarang Regency BPS records, as well as from the Semarang Regency agriculture report records. The frontier stochastic production function was used in this study for several reasons. First, in the yam farming only one output is oriented. Second, to find out the maximum output produced from yam farming. Third, to find out the technical efficiency of yam farming.

The model that used in this study is a production function model with a frontier stochastic production function approach with five independent variables. This model uses an equation in the form of a natural logarithm due to differences in units as well as the use of a data processing tool Frontier 4.1.c. Whereas the mathematical model of the frontier stochastic production function in yam farming is as follows:

$$
\operatorname{LnY}=b 0+b 1 \operatorname{LnX} 1+b 2 \operatorname{LnX} 2+b 3 \operatorname{LnX} 3+b 4 \operatorname{LnX} 4+b 5 \operatorname{LnX} 5+\mu
$$

Information:

$\mathrm{LnY}=$ natural log of yam production variable $(\mathrm{kg})$

bo $=$ parameter

LnX1 = natural log variable land area (M2)

LnX2 = natural log variable labor $(\mathrm{HOK})$

LnX3 = natural log variable seeds (Stems)

$\mathrm{LnX} 4=$ natural log variable fertilizer $(\mathrm{kg})$

LnX5 = natural log pesticide variable $(\mathrm{Lt})$

b1-b5 = regression coefficient

$\mu=$ residue

\section{RESULTS AND DISCUSSION}

The results of technical efficiency calculations using Frontier Version 4.1c software data processing aids obtained an average value of technical efficiency of 0.751 . The results of these calculations indicate that the use of production factors of yam farming in Semarang Regency is not efficient based on technical aspects, because the calculation results show a number less than 1 . The condition occurs because yam farmers have not been able to combine the use of land area production factors, the number of seeds, manure, urea fertilizer, SP-36 fertilizer and phonska fertilizer to get optimal production. Yam farmers still have a chance to increase their production by 0.249 by combining the factors of production by adding factors to yam production. This is due to manure, land area and urea fertilizer which has a large influence on the increase of production, while SP-36 fertilizer and phonska fertilizer have little effect on increasing the production.

The inneficient of yam farming shows that the combination of the use of production factors has not resulted in optimal production (technical efficiency). Yam production that is not optimal shows that the use of land area production factors, the amount of seeds, manure, urea fertilizer, SP-36 fertilizer and overall phonska fertilizer in yam farming has not been used optimally at a 
fixed cost (price efficiency). These conditions indicate the relationship of technical efficiency with price efficiency in yam farming.

The results of price efficiency in the area of production factors are 9.066. The results indicate that the use of land area has not been efficient based on price aspects. Farmers have not been able to use the area of land production factors optimally on rental costs or taxes fixed land. Farmers can increase the use of land area to achieve price efficiency. The majority of farmers do not plant yam in full in a year but alternates with other plants such as vegetables and also corn or rice so that the use of land area cannot be optimal. Under these conditions, farmers can reduce other production factors such as SP-36 fertilizer and phonska fertilizer production so that price efficiency can be achieved.

The result of price efficiency on the seeds is 1.293 The results of these calculations indicate that the use of the number of seed production factors has not been efficient based on price aspects, because the calculation results show a number of more than 1 . The condition occurs because farmers have not been able to achieve good and efficient seed price. Farmers can increase the use of the number of seed production factors to achieve price efficiency. Yam farmers mostly use vegetative seeds in planting yam. Some of the seeds used are picked from previous plants and some are bought. Generally the seeds purchased by farmers are good quality seeds so the price is expensive. If farmers only rely on seeds improperly, the yields are not good enough so that not a few of them who prefer to buy. Therefore, farmers must increase the number of seeds for planting yam so that the price efficiency of the number of seeds can be achieved.

The results of price efficiency in organic fertilizer (manure production) amounted to 1.883 . The results of these calculations indicate that the use of manure production factors in yam farming has not been efficient based on price aspects, because the calculation results show more than 1. The condition occurs because farmers have not been able to use the optimal factor of organic fertilizer at the cost of purchasing fertilizer that remains. Yam farmers can increase the use of fertilizer to achieve price efficiency. Farmers mostly plant yam using manure or compost. The use of manure is felt to be more fertile and cheaper. However, the use of manure is not obtained free of charge but farmers also have to buy it especially for farmers who do not have livestock. Therefore, farmers must add manure to plant yam so that the efficiency of manure prices can be achieved. The provision of high organic matter can add essential nutrients and can also increase the availability of nutrients in the soil for plants, especially the element $\mathrm{N}$ whose main function is for vegetative development of plants such as leaf formation (Raihan, 2001). The number and area of leaves will greatly affect the process of photosynthesis. If the number of leaves is large, the ability to photosynthesize is higher than the number of smaller leaves (Sutanto, 2014).

The results of price efficiency in the urea fertilizer production factor are 1,435 . The results of the calculation show that the use of urea fertilizer production factors in yam farming has not been efficient based on price aspects, because the results is more than 1 . This is due to the farmers have not been able to use the urea fertilizer production factors optimally at the certain cost. Farmers can increase the use of urea fertilizer production factors to achieve price efficiency. Farmers mostly plant yam using urea fertilizer in addition to organic fertilizer. Therefore, farmers must add urea fertilizer for planting yam so that the efficiency of urea fertilizer prices can be achieved.

The result of price efficiency on the SP-36 fertilizer production factor is 1.730 . The results indicate that the use of SP-36 fertilizer production factors in yam farming has not been efficient based on price aspects, because the calculation results show a number of more than 1 . The condition occurs because farmers have not been able to use the SP-36 fertilizer production factor optimally on fixed SP-36 fertilizer costs. Farmers can increase the use of SP-36 fertilizer production factors to achieve price efficiency.

The result of price efficiency in the phonska fertilizer production factor is 3.826 . The results of the calculation show that the use of phonska fertilizer has not been efficient based on price aspects, because the results show a number of more than 1 . The condition occurs because farmers have not been able to use the phonska fertilizer production factor optimally. Farmers can increase 
the use of phonska fertilizer production factors to achieve price efficiency.

The result of the price efficiency is 19,233 . It shows that the use of production factors in yam farming has not yet been reached as an efficient price because the calculation results show a number of more than 1 . The condition happens because farmers have not been able to optimize the use of land area, the seeds, manure (organic fertilizer), urea, SP-36 and phonska optimally at the cost of fixed factors of production. Farmers can optimize the use of production factors by adding production factors to yam farming so that price efficiency could be achieved.

The results of of economic efficiency amounted to 14,433. This findings show that the use of production factors has not been efficient based on economic aspects, because the calculation results show a number of more than 1. The condition occurs because farmers have not been able to combine land area, seeds, manure, urea, SP-36 and phonska are optimally at a fixed factor production cost. So that the production of yam is not optimal. Farmers can combine and optimize the use of production factors in yam farming by increasing the use of manure and urea as well as reducing the SP-36 and phonska. The use of production factors as a whole is not optimal at the cost of fixed factors of production (price efficiency). Therefore, the production has not been optimal (technical efficiency).

The results of the calculation of technical efficiency is 0.751 . This condition shows that the use of production factors in yam farming in Semarang Regency has not been efficient. Farmers in Semarang Regency have not been able to combine the use of land area, seeds, manure, urea, SP-36 and phonska to produce optimal production based on technical aspects. The inefficient cultivation of yam is technically caused by the fact that the cultivation is not carried out fully by farmers in a year but alternates with other plants such as vegetables and also corn or rice so that the use of land area cannot be optimal. In addition, farmers sometimes do not take into account the amount of seed used so that the planting is not yet optimum.

Seed being inneficient based on price aspects because farmers have not used calculations in the seed planting process. The use of seeds is generally as much as 20,000 stems on an area of $10,000 \mathrm{~m} 2$, but in reality most farmers in Semarang Regency actually use less than 20,000 stems, namely less than 15,000 stems, so the yields obtained are not optimal. Under these conditions, farmers can increase the use of seed production factors so that price efficiency can be achieved.

The inefficiency of organic fertilizer in terms of price is due to the fact that farmers in Semarang Regency have not done a thorough calculation in the use of these fertilizer. There are those who use manure excessively, and there are also those who are lacking in using these. Normally, in an area of around 1,000 m2 sweet potato farmers can use $300-500 \mathrm{~kg}$ of manure. However, most farmers only use 100-200 kg because they will be mixed with artificial fertilizers. There are also farmers who only have land area of only about $100 \mathrm{~m} 2$ instead using manure as much as $100 \mathrm{~kg}$. Yam farmers must be more careful in calculating the use of manure in order to achieve price efficiency.

The use of SP-36 fertilizer which is not efficient based on the price aspect is caused by the farmers only use SP-36 fertilizer as a supplementary fertilizer so that its use is very minimal. Farmers in Semarang Regency prefer to use organic fertilizer and also urea fertilizer. The average use of SP-36 fertilizer in yam cultivation in Semarang Regency is only around $10 \mathrm{~kg} / \mathrm{ha}$, which means it is still very minimal. The use of SP-36 fertilizer in yam cultivation in Semarang Regency must be increased in order to achieve price efficiency.

The use of phonska fertilizer has not been efficient because of the price is more expensive compared to other fertilizers. In addition, the availability of subsidized fertilizer which is very low. Farmers need to increase the use of phonska fertilizer so that price efficiency can be achieved. The condition of yam farming in Semarang Regency which is not yet efficient due to all the production factors used by farmers in Semarang Regency are not yet efficient. Farmers generally tend to reduce the use of production factors to reduce production costs. And this precisely causes the price efficiency of yam farming has not been achieved due to the lack of production factors used.

Yam farmers in Semarang Regency generally cultivate yam by vegetative means of cuttings to save the cost of seed input. However, in the cultivation of these cuttings the majority of farmers 
use broodstock seeds that are extracted more than 4 times so that the results cannot be optimal and even the resulting yam are smaller. In addition, spacing that is too tenuous is also one of the causes of suboptimal production. In addition, the use of fertilizer production factors which include organic fertilizer, urea, SP36 and phonska which is very minimal causes the resulting yam are also not optimal. Yam farmers can combine and optimize the use of production factors in yam farming. The use of production factors as a whole is not optimal at the cost of fixed factors of production (price efficiency). Therefore, yam production has not been optimal (technical efficiency).

\section{CONCLUSIONS AND SUGGESTION}

Based on the results of the research, the use of production factors in yam farming in Semarang Regency has not been efficient. Farmers in Semarang Regency have not been able to combine the use of land area production factors, the amount of seeds, organic fertilizer, urea, SP36, and phonska fertilizer to produce optimal yam production based on technical aspectsThe results show that the use of production factors in yam farming has not efficient base on price efficiency. The condition happened due to the farmers have not been able to optimize the use of land area, seeds, organic fertilizer, urea, SP-36, and phonska at the cost of fixed factors of production. Farmers can optimize the use of production factors by adding production factors to yam farming so that price efficiency is achieved. The calculation results show that the use of production factors in yam farming has not been efficient based on economic aspects. The condition occurs because farmers have not been able to combine the land area, seeds, organic fertilizer, urea, SP-36, and phonska, optimally at a fixed factor production cost. So that the production of yam is not optimal.

\section{REFERENCES}

Andoko, A. (2002). Organic Rice Cultivation. Penebar Swadaya. Jakarta

Arikunto, S. (1992). Research Procedure: Practical Approach. Rineka Cipta. Jakarta

BPS atau Statistics Indonesia. (2016). Indonesian workers. retrieved from https://bps.go.id.

Center for Agricultural Data and Information Systems. (2018). Agriculture Sector Employment Statistics 2017-2018. Jakarta: Center for Agricultural Data and Information Systems Secretariat General - Ministry of Agriculture 2018.

Central Bureau of Statistics. (2016). Sweet Potato Production in Central Java. Website: https://bps.go.id. (accessed June 7, 2017).

Central Bureau of Statistics. (2016). Sweet Potato Production in Semarang Regency. Website: https://bps.go.id. (accessed June 7, 2017).

Center for Research and Development of Food Crops. [Research and Development Center]. (2007). Improving Food Quality. Bogor: Center for Research and Development of Food Crops.

Center for Agricultural Data and Information Systems. (2019). Consumption Bulletin. Jakarta: Center for Agricultural Data and Information Systems. Vol 10 (1) 2019.

Defri K. (2011). Analysis of Income and Factors Affecting Sweet Potato Farm Production (Case Study: Purwasari Village, Darmaga District, Bogor Regency). [Thesis]. Bogor: Faculty of Economics and Management, Bogor Agricultural University.

Ekoningtyas, EA, Triwiyatini \& Nisa. F, (2016). Potential Chemical Content of Purple Sweet Potatoes (Ipomoea batatas L) As An Identification Material For The Existence Of Plaque On The Tooth Surface. Jurnal Kesehatan Gigi. 3 (1): 1-6.

Hou, F. (2019). Mulch with plastic film improves the quality of summer sweet potato roots sown (Ipomoea batatas (left). Lam.) In northern China. Journal of Integrative Agriculture.18 (5): 982-1991.

Iswardono (2004) Microeconomic Theory. Gunadarma Publisher. Jakarta

Karama, S. (2003). Potential, challenges, and challenges of cassava in supporting food security, p.1-14. In: Koes Hartojo et al. (ed.). The empowerment of cassava supports national food 
security and the development of community agribusiness. Bean and Tuber Crops Research Institute. Agricultural Research and Development Agency.

Khotimah, Khusnul. (2010). Revenue and Technical Efficiency of Sweet Potatoes in West Java: Stochastic Frontier Support. Agribusiness Journal. 2 (1)

Lau L.J, Yotopoulos P.A. (1971). A Relative Efficiency Test and Application for Indian Agriculture. The American Economic Review, 61 (1): 94-110.

Leovita, A, Asmarantaka, R.W, Daryanto, H.K.S. (2015). Analysis of Revenue and Technical Efficiency of Sweet Potato Farming in Ampek Angkek District, Agam Regency, West Sumatra Province. Jurnal Agribisnis. 3 (1) 2015.

Leovita, A. (2018). Economic Efficiency Analysis of Sweet Potato Farming in Ampek Angkek District, Agam Regency, West Sumatra. Artikel menara Ilmu. 12 (9) 2018.

Ministry of Agriculture. (2019). Data of the Last Five Years. Website: https://pertanian.go.id. (accessed 12 October 2019)

Mubyarto (1994). Introduction to Agricultural Economics. Jakarta: LP3ES

Nicholson, W. (2002). Intermediate Microeconomics. Eighth edition. Erlangga Jakarta.

Nurmalina, R. (2008). Analysis of Index and Status of Rice System Sustainability in Several Regions in Indonesia. Agro Economic Journal. 26 (1): 47-79.

Prihandayani, IH. (2014). Efficiency Analysis of the Use of Production Factors in Sweet Potato Farming. [Thesis]. Diponegoro University's Faculty of Economics and Business.

Raihan, H\&Nurtirtayani. (2001). The Effect of Provision of Organic Materials on the N and P Distribution of Soil Available and the Results of Several Corn Varieties in Tidal Sulfate Tides. Agrivita Journal. 23 (1): 13-21.

Ratih, F. (2012). Technical Efficiency of Sweet Potato Farming in Cikarawang, Bogor Regency, West Java. [Thesis]. Bogor: Faculty of Economics and Management, Bogor Agricultural University.

Santosa, T (2012). Efficient Use of Factors for Production of Sweet Potatoes Malang, Indonesia. 17 (1): 21-32.

Santoso, W.E.A\&Estiasih, T (2014). "Purple Sweet Potato Co-pigmentation (Ipomoea batatas var. Ayamurasaki) With Na-Caseinate and Whey Protein Kopigmen And Their Stability Against Stability Use. Jurnal Pangan dan Agroindustri. 2 (4): 121-127.

Setiawan, A. B., \& Bowo, P. A. (2015). Technical, Allocative, and Economic Efficiencies of Rice cultivation. JEJAK: Jurnal Ekonomi dan Kebijakan, 8(2), 149-159.

Suparman. (2007). Farming for Sweet Potatoes. Azka Mulia Media. Jakarta.

Sutanto, E. (2014). Growth response and yield of sweet potato (Ipomoea batatas L) in several kinds and times of application of organic matter. Brawijaya University. Malang . Jurnal Produksi Tanaman. Vol 4 (1): 37-41.

Soekartawi. (2003). Basic Principles of Agricultural Economics (Theory and Application). 2nd ed. Jakarta: PT Raja Grafindo Persada.

Waramboi, J.G., Dennien, S., Gidley, J.M., Sopade, A.P. (2011). Characterization of sweet potatoes from Papua New Guinea and Australia: Physicochemical properties, pastes and gelatinization. Food Chemistry .126: 1759-1770.

Wikipedia. (2019). "Plastic mulch". Website: https://id.wikipedia.org. (accessed 5 October 2019)

Zhang, T\&Oates, C.G. (1999). Relationship between amylase degradation and physicochemical properties of sweet potato starch. Food Chemistry (65) 157-163.

Zuraida, N. (2009). Status of Sweet Potatoes as Carbohydrate Source Food Diversification Material. IPTEK Tanaman Pangan. 4 (1): 69-80. 